\title{
Kajian Saintifik Fenomena Adiksi Gadget dan Media Sosial di Indonesia
}

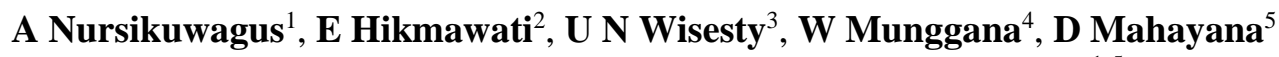 \\ Teknik Elektro dan Informatika, Institut Teknologi Bandung ${ }^{1-5}$ \\ Jl. Ganesha No.10, Bandung, 40132, Indonesia ${ }^{1-5}$ \\ agusnursikuwagus@email.unikom.ac.id ${ }^{1}$,Erna@pasim.ac.id*2, untarinw@telkomuniversity.ac.id ${ }^{3}$, \\ wira@umn.ac.id ${ }^{4}$, dimitri@1skk.ee.itb.ac.id ${ }^{5}$ \\ diterima: 13 Desember 2019 \\ direvisi: 17 Februari 2020 \\ dipublikasi: 1 Maret 2020
}

\begin{abstract}
Abstrak
Penggunaan Gadget dan Media sosial saat ini tidak bisa dipisahkan dari kehidupan sehari-hari. Hal ini dapat menyebabkan adanya adiksi gadget dan media sosial. Penelitian ini bertujuan untuk menjawab apakah fenomena adiksi gadget dan media sosial merupakan kenyataan saintifik atau tidak di Indonesia. Pengumpulan data dilakukan dengan survei kepada 1312 responden. Sebelum kuesioner disebarkan, dilakukan uji validitas Pearson Product Momen dan uji reliabilitas dengan Cronbach's Alpha dan hasilnya menunjukan bahwa seluruh pertanyaan pada kuesioner valid dan reliable. Berdasarkan hasil survei, $42.45 \%$ responden mengalami kecanduan ringan, $10.82 \%$ responden mengalami kecanduan level sedang, dan $0.38 \%$ responden mengalami kecanduan yang sangat kuat terhadap gadget. Sedangkan hasil untuk adiksi media sosial, $37.50 \%$ responden mengalami kecanduan ringan, $7.85 \%$ responden mengalami kecanduan level sedang, dan $0.38 \%$ responden mengalami kecanduan yang sangat kuat terhadap media sosial. Dilihat dari sisi filsafat ilmu, Adiksi Gadget dan social media dikatakan sains dan bukan pseudo sains karena telah memenuhi ciri sains yaitu logis, empiris, dan dapat difalsifikasi. Sehingga perlu perhatian khusus dari masyarakat akan adanya adiksi gadget dan media social ini, agar adiksi ini dapat diantisipasi dan gejala-gejala yang ditimbulkan dapat diminimalisir.
\end{abstract}

Kata kunci: Adiksi; Gadget; Media Sosial; Filsafat Ilmu

\begin{abstract}
The use of Gadgets and Social Media at this time can not be separated from everyday life. This can lead to gadget and social media addiction. This study aims to answer whether the phenomenon of gadget addiction and social media is a scientific reality or not in Indonesia. Data was collected by a survei of 1601 respondents. Before the questionnaire was distributed, pearson product moment validity and reliability tests were performed with Cronbach's alpha and the results showed that all questions on the questionnaire were valid and reliable. Based on the survei results, $42.45 \%$ of respondents experienced mild addiction, 10.82\% of respondents experienced moderate level of addiction, and $0.38 \%$ of respondents experienced a very strong addiction to gadget. While the results for social media addiction, $37.50 \%$ of respondents experienced mild addiction, $7.85 \%$ of respondents experienced moderate level of addiction, and $0.38 \%$ of respondents experienced a very strong addiction to social media. In terms of the philosophy of science, Gadgets and Social Media Addiction is said to be science and not pseudo science because it has fulfilled the characteristics of science that is logical, empirical, and falsifiable. So it needs special attention from the community on the existence of gadget and media sosial addiction, so that this addiction can be anticipated and the symptoms can be minimized.
\end{abstract}

Keywords: Addiction; Gadget; Social Media; Philosophy of Science

\section{Pendahuluan}

Penggunaan Gadget dan Media sosial saat ini tidak bisa dipisahkan dari kehidupan seharihari. Penggunaan gadget dan media sosial saat ini tidak bisa dipisahkan dari kehidupan 
sehari-hari. Semakin beragamnya jenis gadget yang diproduksi oleh berbagai perusahaan besar dengan suguhan aplikasi-aplikasi yang canggih dalam menyajikan berbagai media berita, jejaring social, informasi gaya hidup dan hobi secara online maupun offline kini sukses menarik banyak perhatian dari masyarakat [1]. Gadget pada jaman sekarang sangat mudah ditemukan, hampir di setiap kalangan masyarakat memiliki gadget [2]. Bahkan menurut statista.com, jumlah pengguna gadget di Indonesia pada tahun 2018 mencapai 320.77 juta orang [3].

Perkembangan teknologi yang semakin canggih memberikan suatu perubahan yang besar dalam komunikasi yang dilakukan oleh masyarakat di era modern [4]. Dengan media social kehidupan dunia nyata dapat ditransformasi ke dalam dunia maya. Masyarakat dapat dengan bebas berbagi informasi dan berkomunikasi dengan banyak orang tanpa perlu memikirkan hambatan dalam hal biaya, jarak dan waktu [5].

Di sisi lain, dibalik kemudahan yang ditawarkan oleh teknologi seperti gadget dan media sosial terdapat sesuatu dampak yang dapat merugikan dan memberikan pengaruh negative salah satunya yaitu adiksi. Awalnya konsep adiksi menjadi perdebatan besar selama bertahun-tahun. Konsep tersebut tidaklah mudah untuk didefinisikan tetapi hal itu bergantung dari aktivitas yang dilakukan [6]. Gadget sudah menjadi gaya hidup masyarakat modern tetapi kecanduan gadget memiliki konsekuensi negatif terhadap kehidupan seharihari [7]. Kehadiran gadget dapat berpengaruh terhadap interaksi social, baik pengaruh positif maupun negatif [8]. Pengaruh positif di antaranya adalah memudahkan dalam berkomunikasi walau jarak jauh. Sedangkan pengaruh negatif di antaranya adalah dapat menjadikan remaja mengalami disfungsi, waktu interaksi tatap muka langsung berkurang, kehadiran gadget mengganggu kualitas interaksi langsung, gadget menjadikan remaja hyperpersonal, gadget menjadikan remaja konsumtif dan gadget membuat remaja kurang peka terhadap lingkungan sekitar [8]. Selain itu, Adiksi gadget dapat berdampak pada perkembangan anak dan remaja yaitu gangguan emosi dan perilaku [9].

Fenomena adiksi media sosial dapat dikategorikan sebagai behavioral addiction, dimana seseorang yang sudah teradiksi tidak dapat mengontrol dirinya sendiri untuk mengontrol penggunaan media sosial dan terlalu banyak menghabiskan waktu dan usaha untuk mengakses media sosial, sehingga perilaku tersebut dapat mengganggu produktivitas. Adiksi bermula dari produksi dopamin dalam otak yang dipicu oleh likes, retweets, share, dan reaksi emoticon yang didapat oleh orang tersebut. Fenomena ini mirip dengan reaksi kimia yang disebabkan oleh narkoba, minuman keras, dan perjudian [10].

Penelitian ini dilakukan dengan tujuan untuk menjawab apakah fenomena adiksi gadget dan media sosial merupakan kenyataan saintifik atau tidak di Indonesia. Metodologi penelitian yang digunakan adalah metode kuantitatif deskriptif dengan melakukan survei kepada 1312 responden untuk melihat adanya adiksi gadget dan media sosial di Indonesia. Selain itu dilakukan kajian dari sisi filsafat ilmu untuk memperkuat bahwa adiksi gadget dan media sosial merupakan realitas saintifik.

\section{Kajian Pustaka}

Pada bagian ini dijelaskan teori-teori dasar tentang Adiksi Gadget dan Media sosial serta teori pendukung yang digunakan pada penelitian.

\subsection{Adiksi Gadget dan Media Sosial}

Fenomena adiksi gadget media sosial dapat dikategorikan sebagai behavioral addiction, dimana seseorang yang sudah teradiksi tidak dapat mengontrol dirinya sendiri untuk menggunakan media sosial dan terlalu banyak menghabiskan waktu dan usaha untuk mengakses media sosial, sehingga perilaku tersebut dapat mengganggu produktivitas [10]. Adiksi media sosial dipengaruhi oleh produksi dopamine dalam dalam otak yang ditrigger 
oleh likes, retweets, share, dan reaksi emoticon yang didapat oleh orang tersebut. Fenomena ini mirip dengan reaksi kimia yang disebabkan oleh narkoba, minuman keras, dan perjudian.

Berdasarkan penelitian yang dilakukan di Harvard University, interaksi dalam jarinan social dapat mempengaruhi bagian otak yang berhubungan dengan sensasi dan pengambilan keputusan. Ketika seseorang mendapatkan penghargaan secara instan maka area produksi dopamine dalam otak akan aktif dan produksi dopamin akan meningkat. Media Sosial dapat memberikan penghargaan instan ini secara terus menerus dan dengan usaha yang relative minimal. Area dalam otak ini akan lebih aktif jika seseorang menceritakan tentang dirinya sendiri, dan media sosial sebenarnya sering digunakan seseorang untuk menceritakan kehidupannya sendiri dan pencapaian-pencapaian apa yang telah berhasil didapatkan.

Adiksi media sosial akan semakin parah ketika seseorang menggunakan media sosial tersebut untuk menghilangkan stress, kesepian, atau depresi. Hal ini juga dapat menyebabkan masalah interpersonal yang meliputi mengabaikan hubungan sosial dalam dunia nyata, tanggung jawab perkerjaan atau sekolah, dan kesehatan fisik. Dalam penelitian yang dilakukan oleh California State University, dinyatakan bahwa seseorang yang menggunakan media sosial minimal 58 kali setiap minggunya merasa tiga kali lebih terisolasi dan depresi dibandingkan dengan seseorang yang hanya menggunakan media sosial maksimal sembilan kali setiap minggunya. Pesan terisolasi dan depresi ini berhubungan dengan terhambatnya komunikasi social pada dunia nyata yang menyebabkan seseorang tersebut tidak dapat menyampaikan atau bergaul dengan orang-orang disekitarnya. J Rahmat [11] menyebutkan tanda-tanda komunikasi yang efektif sebagai berikut:

a. Pengertian, penerimaan yang cermat dari isi pesan seperti yang dimaksud oleh komunikator.

b. Kesenangan, komunikasi fatis, komunikasi yang menjadikan hubungan dengan orang lain menjadi hangat, akrab, dan menyenangkan.

c. Persuasi, proses mempengaruhi pendapat, sikap, dan tindakan dengan menggunakan manipulasi psikologis sehingga orang tersebut bertindak seperti atas kehendaknya sendiri.

d. Hubungan social yang baik, dikarenakan pada dasarnya manusia adalah makhluk social.

e. Tindakan, untuk menimbulkan tindakan dari seseorang, harus terlebih dahulu menanamkan pengertian, membentuk dan mengubah sikap, atau menumbuhkan hubungan yang baik.

Dalam bukunya [12], Jaron Lanier juga menjelaskan tentang bahaya media sosial dan berargumen untuk segera menghapus akun media sosial. Beberapa argument Jaron Lanier sebagai berikut:

a. Media sosial dapat memanipulasi perilaku dan mengancam kebebasan dalam membuat keputusan

b. Anda dapat diawasi, dimanipulasi dan dianalisis ketika anda menggunakan media social menggunakan smartphone.

c. Algoritma dalam social media tersebut dapat memprediksi apa yang akan anda lakukan berdasarkan data yang dikompilasi ketika anda login.

d. Perusahaan media sosial tersebut dapat menjual informasi dalam media social anda.

e. Platform media sosial didesain untuk membuat penggunanya menjadi kecanduan, yang berasal dari respon pengguna media sosial lain.

f. Adiksi media sosial dapat membuat anda kehilangan kontak dengan orang-orang di sekitar anda.

g. Model bisnis social media bersifat infasif dan berbahaya. Media sosial dapat berkontribusi pada penyebaran informasi yang salah. 


\subsection{Gejala Adiksi Gadget dan Media Sosial}

Gejala gadget dan media sosial mirip dengan gejala-gejala adiksi lainnya yang meliputi[13]:

a. Mood modification, ketergantungan media social dapat mempengaruhi perubahan emosi seseorang.

b. Salience, perasaan sangat membutuhkan, mendominasi pikiran, dan tingkah laku, yang dipengaruhi oleh media sosial.

c. Tolerance, peningkatan jumlah penggunaan Gadget dan Media Sosial untuk mendapatkan perasaan penghargaan positif dari media social.

d. Withdrawal Symptoms, perasaan yang tidak menyenangkan karna penggunaan Gadget dan Media Sosial dikurangi atau dihentikan.

e. Relapse, kecenderungan seseorang mengulang kembali penggunaan gadget dan media sosial setelah tidak menggunakan media social tersebut.

f. Conflict, konflik yang terjadi antara pengguna Gadget dan Media Sosial dengan lingkungan sekitarnya.

Dalam penelitian lainnya [14], terdapat gejala-gejala lain dari ketergantungan gadget dan media social, yaitu:

a. Loss of control, kehilangan kendali untuk mengontrol penggunaan gadget dan media social.

b. Denial and concealment, berusaha untuk menyembunyikan penggunaan gadget dan media social.

Meskipun banyak orang yang terbiasa untuk menggunakan media social, akan tetapi sangat sedikit yang benar-benar tergantung pada media social tersebut. Berikut enam pertanyaan sederhana yang dapat mendeteksi apakah seseorang mengalami kertergantungan media social atau tidak, jika lebih dari tiga pertanyaan tersebut dijawab dengan "Ya", maka kemungkinan orang tersebut mengalami ketergantungan media social:

a. Apakah seseorang tersebut banyak menghabiskan waktu untuk memikirkan media sosial atau merencanakan untuk menggunakan media sosial?

b. Apakah seseorang tersebut berusaha untuk menggunakan media social secara terus menerus?

c. Apakah seseorang tersebut menggunakan media social untuk melupakan masalahnya?

d. Apakah seseorang tersebut sering berusaha untuk mengurangi menggunakan media social tetapi tidak berhasil?

e. Apakah seseorang tersebut menjadi gelisah ketika tidak dapat menggunakan media social?

f. Apakah seseorang tersebut sanggat sering menggunakan media social sehingga mengganggu pekerjaan atau pendidikannya?

\section{Metode Penelitian}

Penelitian ini bertujuan untuk mengukur tingkat ketergantungan (adiksi) penggunaan gadget dan media social di Indonesia, hubungan antara adiksi gadget dengan adiksi media social, serta pengaruh factor jenis kelamin, usia, profesi, dan domisili dengan tingkat adiksi gadget dan Media Sosial. Penelitian yang dilakukan dimulai dari penyusunan kuisioner, pengambilan sample data untuk uji validitas dan reabilitas kuisioner yang telah disusun, survei data, perhitungan dan klasifikasi tingkat adiksi gadget dan Media Sosial, analisa hasil secara keseluruhan dan setiap kategori yang ditentukan, serta analisa hasil yang diperoleh berdasarkan sudut pandang filsafat ilmu. Metode penelitian yang dilakukan disajikan pada Gambar 1. 


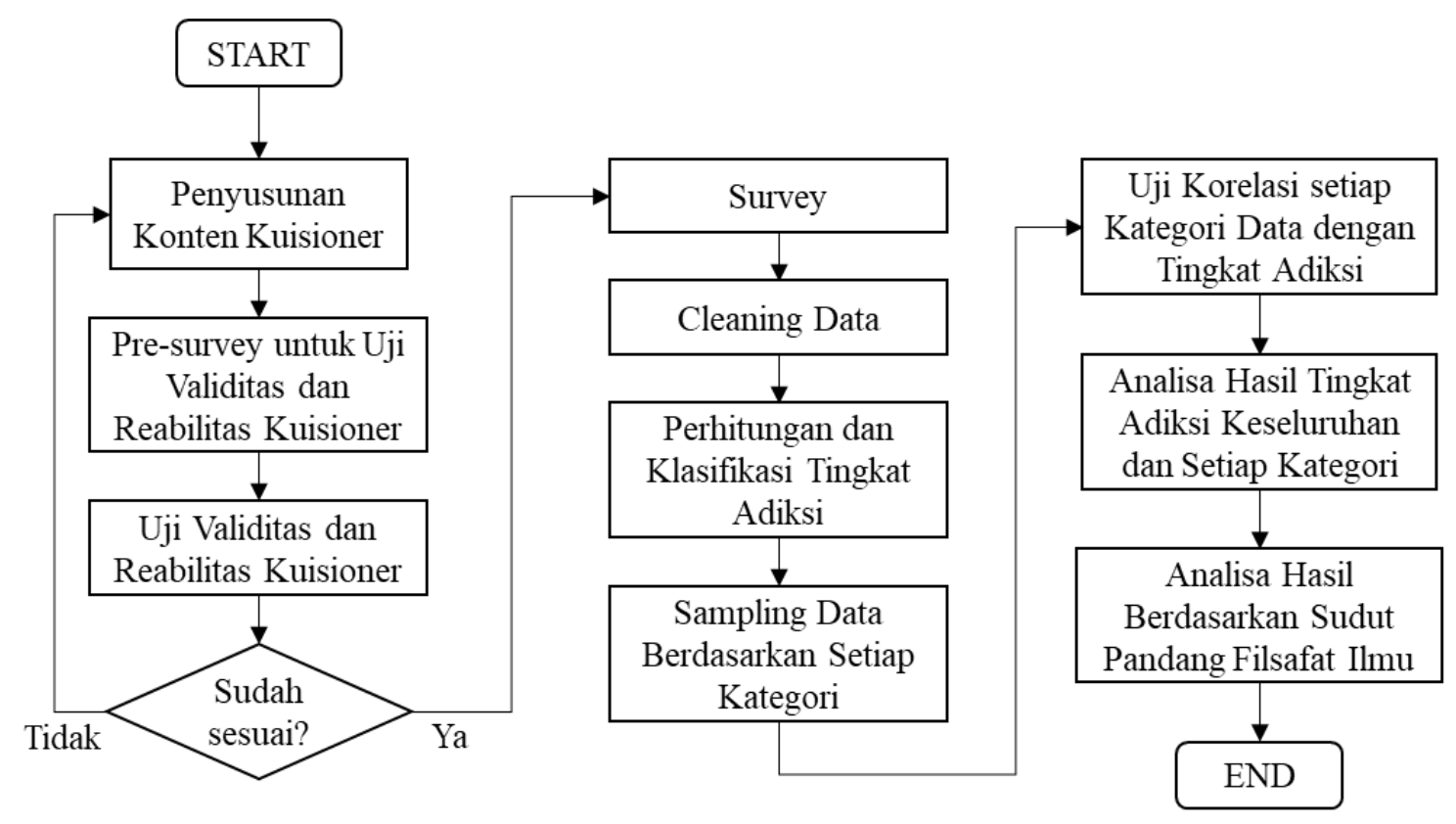

Gambar 1. Metode Penelitian kajian adiksi gadget dan Media Sosial

\subsection{Penyusunan Konten Kuisioner}

Pertanyaan-pertanyaan yang disusun berdasarkan buku Kimberly Young tentang adiksi internet [15]. Pertanyaan-pertanyaan tersebut dibagi ke dalam dua bagian yaitu pertanyaan tentang tingkat penggunaan gadget dan pertanyaan tentang tingkat penggunaan media social yang masing-masing terdiri dari 20 pertanyaan. Pertanyaan-pertanyaan yang berhubungan dengan tingkat penggunaan gadget yaitu:

a. Seberapa sering Anda menemukan bahwa Anda tetap mengakses Gadget lebih lama dari yang Anda inginkan?

b. Seberapa sering Anda mengabaikan pekerjaan rumah tangga/studi untuk menghabiskan lebih banyak waktu mengakses gadget?

c. Seberapa sering Anda lebih memilih Gadget daripada komunikasi dengan keluarga, teman, dan lain-lain?

d. Seberapa sering Anda membentuk hubungan baru dengan sesama pengguna Gadget?

e. Seberapa sering orang lain dalam hidup Anda mengeluh kepada Anda tentang jumlah waktu yang Anda habiskan untuk mengakses Gadget?

f. Seberapa sering nilai sekolah atau pekerjaan Anda terganggu karena Anda sibuk dengan Gadget?

g. Seberapa sering produktivitas Anda terganggu karena Gadget?

h. Seberapa sering Anda memeriksa Gadget sebelum mengerjakan hal lain?

i. Seberapa sering Anda menjadi defensif/bersikap rahasia ketika ada yang bertanya apa yang Anda lakukan saat mengakses Gadget?

j. Seberapa sering Anda menghilangkan pikiran negatif tentang kehidupan Anda dengan beralih pada Gadget?

k. Seberapa sering Anda menemukan diri Anda menolak ketika Anda akan mengakses Gadget lagi?

1. Seberapa sering Anda takut bahwa hidup tanpa Gadget akan membosankan, hampa dan kurang menyenangkan?

m. Seberapa sering Anda kesal jika seseorang mengganggu Anda saat Anda sedang mengakses Gadget?

n. Seberapa sering Anda kurang tidur dikarenakan Gadget? 
o. Seberapa sering Anda memikirkan tentang Gadget ketika sedang tidak mengakses Gadget?

p. Seberapa sering Anda menemukan diri Anda mengatakan "hanya beberapa menit lagi" saat menggunakan Gadget?

q. Seberapa sering Anda mencoba mengurangi waktu yang Anda habiskan untuk Gadget tetapi gagal?

r. Seberapa sering Anda mencoba menyembunyikan berapa lama Anda mengakses Gadget?

s. Seberapa sering Anda memilih untuk menghabiskan lebih banyak waktu untuk Gadget dibandingkan untuk keluar dengan orang lain?

t. Seberapa sering Anda merasa tertekan, murung, atau gugup ketika Anda tanpa Gadget dan akan hilang setelah Anda kembali mengakses Gadget?

Pertanyaan yang berhubungan dengan tingkat penggunaan media social sama dengan tingkat penggunaan gadget dengan pertanyaan berjumlah 20, sebagai berikut.

a. Seberapa sering Anda menemukan bahwa Anda tetap mengakses Media Sosial lebih lama dari yang Anda inginkan?

b. Seberapa sering Anda mengabaikan pekerjaan rumah tangga/studi untuk menghabiskan lebih banyak waktu mengakses Media Sosial?

c. Seberapa sering Anda lebih memilih Media Sosial daripada komunikasi dengan keluarga, teman, dan lain-lain?

d. Seberapa sering Anda membentuk hubungan baru dengan sesama pengguna Media Sosial?

e. Seberapa sering orang lain dalam hidup Anda mengeluh kepada Anda tentang jumlah waktu yang Anda habiskan untuk mengakses Media Sosial?

f. Seberapa sering nilai sekolah atau pekerjaan Anda terganggu karena Anda sibuk dengan Media Sosial?

g. Seberapa sering produktivitas Anda terganggu karena Media Sosial?

h. Seberapa sering Anda memeriksa Media Sosial sebelum mengerjakan hal lain?

i. Seberapa sering Anda menjadi defensif/bersikap rahasia ketika ada yang bertanya apa yang Anda lakukan saat mengakses Media Sosial?

j. Seberapa sering Anda menghilangkan pikiran negatif tentang kehidupan Anda dengan beralih pada Media Sosial?

k. Seberapa sering Anda menemukan diri Anda menolak ketika Anda akan mengakses Media Sosial lagi?

1. Seberapa sering Anda takut bahwa hidup tanpa Media Sosial akan membosankan, hampa dan kurang menyenangkan?

m. Seberapa sering Anda kesal jika seseorang mengganggu Anda saat Anda sedang mengakses Media Sosial?

n. Seberapa sering Anda kurang tidur dikarenakan Media Sosial?

o. Seberapa sering Anda memikirkan tentang Media Sosial ketika sedang tidak mengakses Media Sosial?

p. Seberapa sering Anda menemukan diri Anda mengatakan "hanya beberapa menit lagi" saat menggunakan Media Sosial?

q. Seberapa sering Anda mencoba mengurangi waktu yang Anda habiskan untuk Media Sosial tetapi gagal?

r. Seberapa sering Anda mencoba menyembunyikan berapa lama Anda mengakses Media Sosial? 
s. Seberapa sering Anda memilih untuk menghabiskan lebih banyak waktu untuk Media Sosial dibandingkan untuk keluar dengan orang lain?

t. Seberapa sering Anda merasa tertekan, murung, atau gugup ketika Anda tanpa Media Sosial dan akan hilang setelah Anda kembali mengakses Media Sosial?

Masing-masing pertanyaan tersebut akan memiliki enam opsi jawaban yang juga didasarkan pada survei Kimberly Young beserta konversi ke bilangan numerik (pada Tabel $1)$.

Tabel 1. Opsi Jawaban Kuesioner

\begin{tabular}{|l|l|l|l|}
\hline No & Kimberly Young & Terjemahan & Konversi Nilai \\
\hline 1 & Not Applicable & Tidak Pernah & 0 \\
\hline 2 & Rarely & Jarang & 1 \\
\hline 3 & Occasionally & Kadang-Kadang & 2 \\
\hline 4 & Frequently & Sering & 3 \\
\hline 5 & Often & Sangat Sering & 4 \\
\hline 6 & Always & Selalu & 5 \\
\hline
\end{tabular}

\subsection{Pre-survei dan Uji Validitas dan Reabilitas Kuisioner}

Kuisioner yang sudah disusun, kemudian dilakukan pre-survei kepada sample responden yang berjumlah kecil untuk dilakukan uji validitas dan reabilitas. Pre-survei dilakukan sebanyak dua kali yaitu tanggal 5-6 November 2019 dengan total responden 143 orang dan 7-8 November 2019 dengan total responden 114 orang (setelah cleaning data).

Uji validitas menyatakan ketepatan dan kecermatan alat ukur dalam melakukan fungsinya, sedangkan uji reabilitas yaitu sejauh mana alat ukur mampu memberikan informasi yang sebenarnya dari kuisioner yang disusun. Dalam penelitian ini uji validitas dilakukan menggunakan perhitungan korelasi Product Moment (Persamaan 1) dan uji reabilitas menggunakan metode Cronbach's Alpha (Persamaan 2).

$\mathrm{r}_{x y}=\frac{N \sum x y-\left(\sum x\right)\left(\sum y\right)}{\sqrt{\left\{N \sum x^{2}-\left(\sum x\right)^{2}\right\}\left\{N \sum y^{2}-\left(\sum y\right)^{2}\right\}}}$

Dimana: $\quad \mathrm{r}_{x y}$ : koefisien korelasi antara variable $x$ dan variable $y$

$N$ : jumlah sample data

$r_{11}=\left(\frac{n}{n-1}\right)\left(1-\frac{\sum \sigma_{t}^{2}}{\sigma_{t}}\right)$

Dimana: $\quad r_{11}$ : nilai reabilitas yang dicari

$n$ : jumlah item pertanyaan yang diuji

$\sigma_{t}$ : nilai variansi setiap item

\subsection{Survei dan Cleaning Data}

Setelah dilakukan uji validitas dan reabilitas setiap item pertanyaan dalam kuisioner, dilakukan survei pada tanggal 11-17 November 2019 dan menghasilkan 1782 data mentah. Kemudian dilakukan cleaning data untuk mengeliminasi data yang redundan dan data yang tidak sesuai (misal data dengan umur dibawah 17 tahun atau data yang terdapat kesalahan 
pengisian). Proses cleaning data tersebut menghasilkan 1693 data yang siap diolah pada langkah berikutnya.

\subsection{Perhitungan dan Klasifikasi Tingkat Adiksi Gadget dan Media Sosial}

Sebelum melakukan perhitungan tingkat adiksi gadget dan Media Sosial dari hasil suvey yang telah melalui proses cleaning data, jawaban hasil survei yang bertipe string perlu dikonversi dulu ke bilangan numerik supaya dapat dilakukan perhitungan matematis (konversi nilai disajikan pada Tabel 2). Perhitungan tingkat adiksi gadget dan adiksi Media Sosial dilakukan dengan menjumlahkan setiap jawaban survei pada masing-masing responden. Total skor tingkat adiksi tersebut memiliki rentang nilai dari 0 sampai 100. Kemudian, dari total skor yang telah didapatkan, responden tersebut dapat diklasifikasikan tingkat adiksinya sesuai dengan kriteria tingkat adiksi yang disajikan dalam Tabel 2.

Tabel 2. Konversi Nilai Adiksi

\begin{tabular}{|c|l|}
\hline Skor & \multicolumn{1}{|c|}{ Deskripsi } \\
\hline $0-30$ & Mencerminkan tingkat penggunaan Gadget dan Media Sosial yang normal. \\
\hline $31-49$ & $\begin{array}{l}\text { Menunjukkan tingkat kecanduan Gadget dan Media Sosial yang ringan } \\
\text { (mild). }\end{array}$ \\
\hline $50-79$ & $\begin{array}{l}\text { Menunjukkan tingkat kecanduan Gadget dan Media Sosial yang sedang } \\
\text { (moderate). }\end{array}$ \\
\hline $80-100$ & $\begin{array}{l}\text { Menunjukkan tingkat ketergantungan yang sangat kuat pada Gadget dan } \\
\text { Media Sosial (severe). }\end{array}$ \\
\hline
\end{tabular}

\subsection{Sampling Data Berdasarkan Kategori Jenis Kelamin, Usia, Profesi, dan Domisili}

Selain menganalisa hasil tingkat adiksi gadget dan Media Sosial dari keseluruhan data, akan dianalisa korelasi antara faktor jenis kelamin, usia, profesi, dan domisili dengan tingkat adiksi gadget dan Media Sosial. Oleh karena itu, dibutuhkan pengambilan sampel untuk masing-masing kategori dari data keseluruhan. Pada penelitian ini, digunakan proporsi sample berdasarkan jenis kelamin yaitu 51\% pria dan $49 \%$ [16] wanita menggunakan metode random sampling.

Strata yang digunakan pada masing-masing kategori jenis kelamin, usia, profesi, dan domisili dengan tingkat adiksi gadget dan Media Sosial yaitu:

a. Jenis kelamin: pria dan wanita.

b. Profesi: Pelajar, pengajar, karyawan, dan lainnya.

c. Domisili: nuar negeri, pulau jawa, dan luar pulau jawa.

d. Usia: remaja akhir (17-25 tahun), dewasa awal (26-35 tahun), dewasa akhir (36-45 tahun), lansia awal (46-55 tahun), dan lansia akhir (56-65 tahun) [17]

\section{Hasil dan Pembahasan}

Pada bagian ini akan dipaparkan hasil yang didapatkan dari survei. Selain itu akan disajikan juga kajian adiksi gadget dan media sosial dilihat dari Filsafat Ilmu.

\subsection{Hasil Penelitian}

Dari hasil survei terhadap 1312 responden, didapatkan hasil bahwa $42.45 \%$ responden teradiksi ringan, $10.82 \%$ responden teradiksi sedang, dan $0.38 \%$ responden teradiksi tinggi terhadap gadget. Sedangkan hasil adiksi pada media social yaitu $37.50 \%$ responden teradiksi ringan, $7.85 \%$ teradiksi sedang dan $0.38 \%$ teradiksi tinggi. Hasil tersebut dapat dilihat pada gambar 2 . 


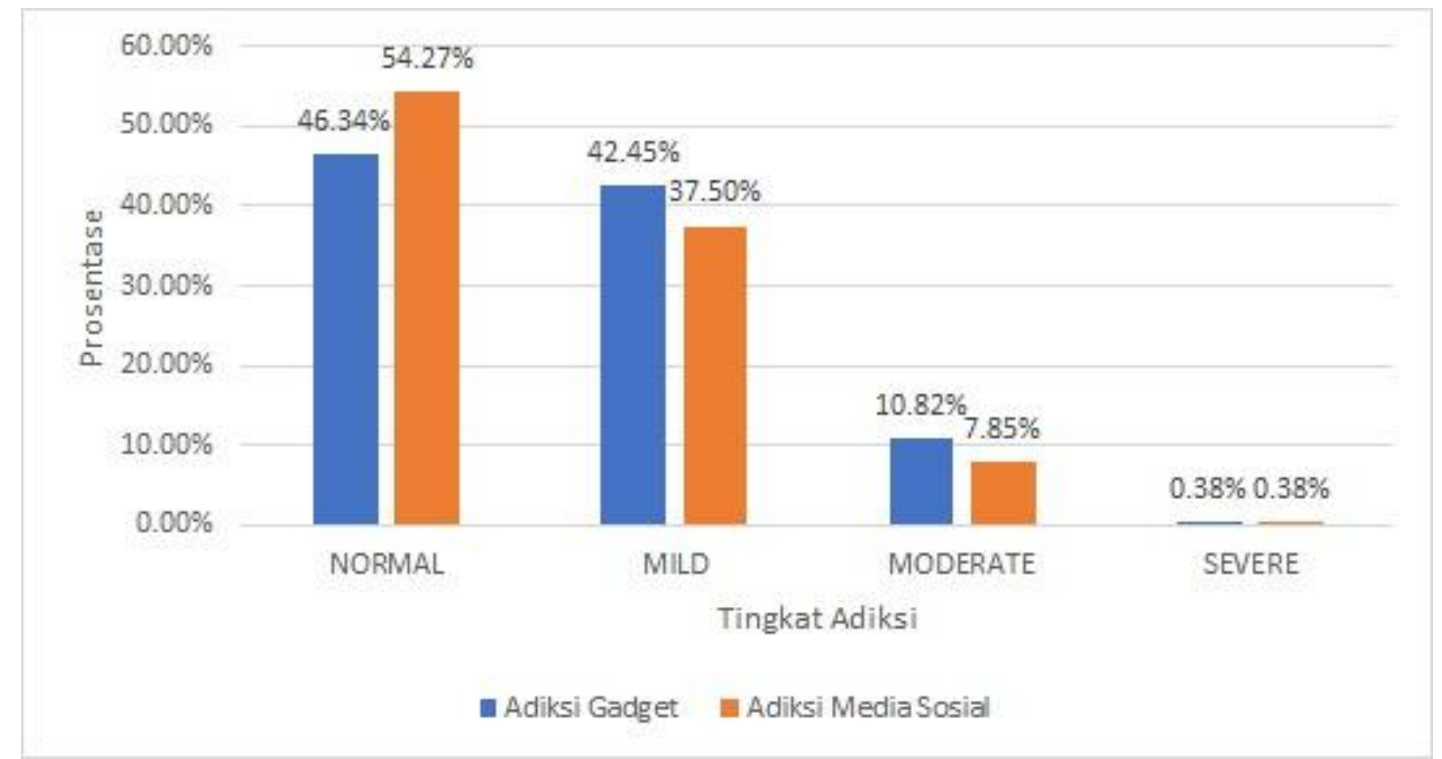

Gambar 2. Hasil Adiksi Gagdet dan sosial media secara keseluruhan

Gambar 3-7 menunjukan hasil adiksi gadget berdasarkan beberapa variable uji jenis kelamin, kelompok umur, profesi, tingkat pendidikan dan domisili:

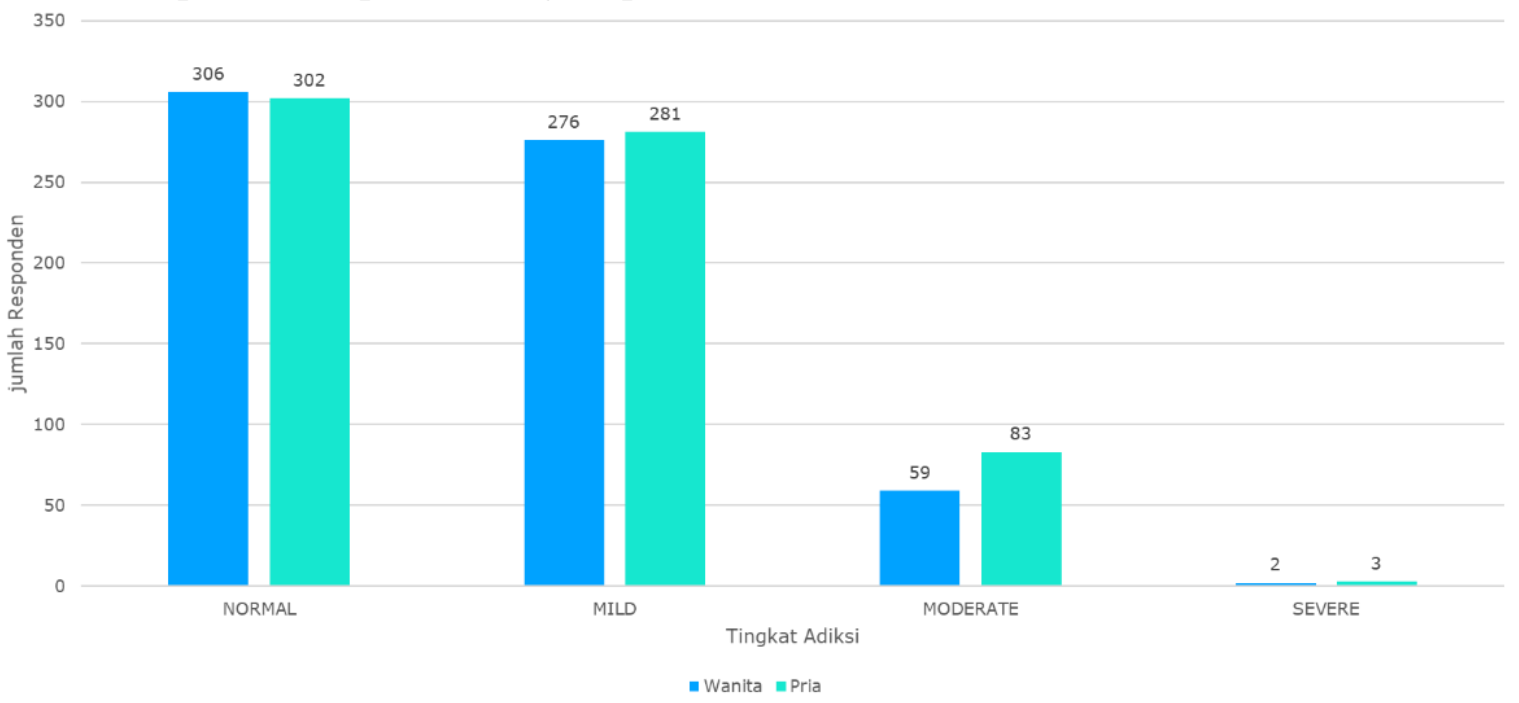

Gambar 3. Hasil Adiksi Gagdet berdasarkan Jenis Kelamin

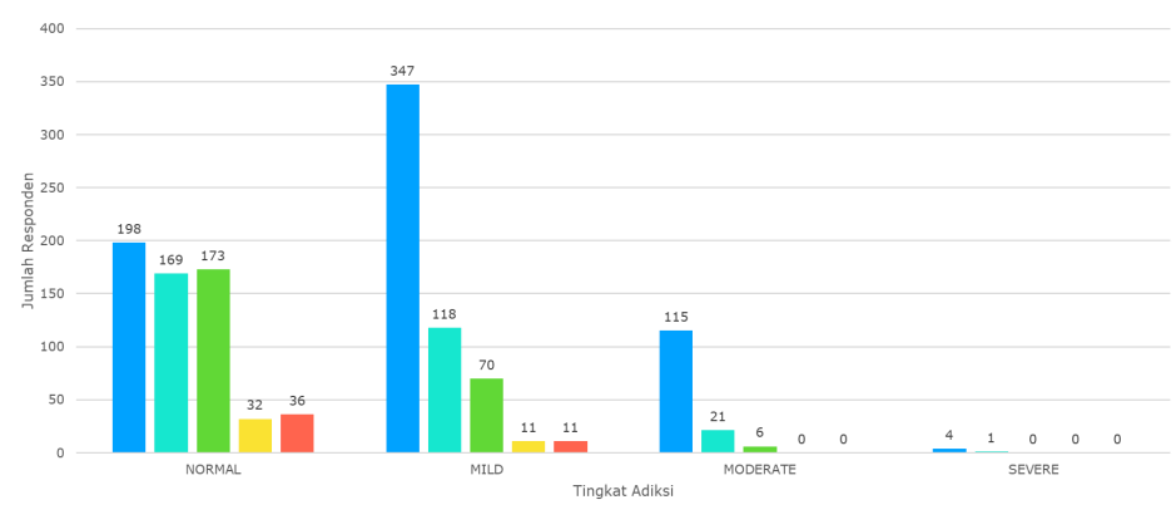

Gambar 4. Hasil Adiksi Gagdet berdasarkan Kelompok Umur 


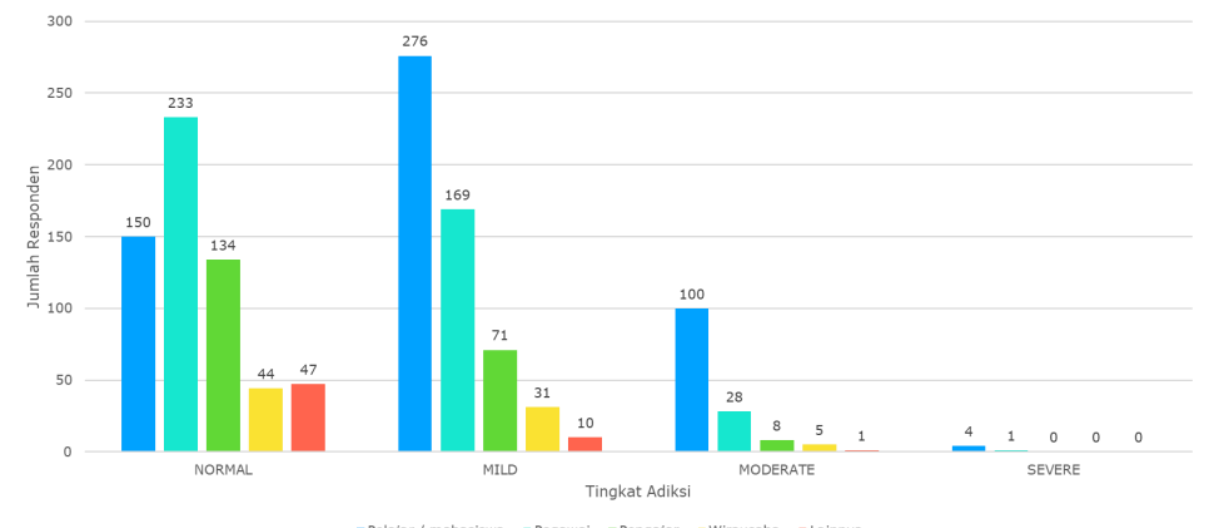

Gambar 5. Hasil Adiksi Gagdet berdasarkan Profesi

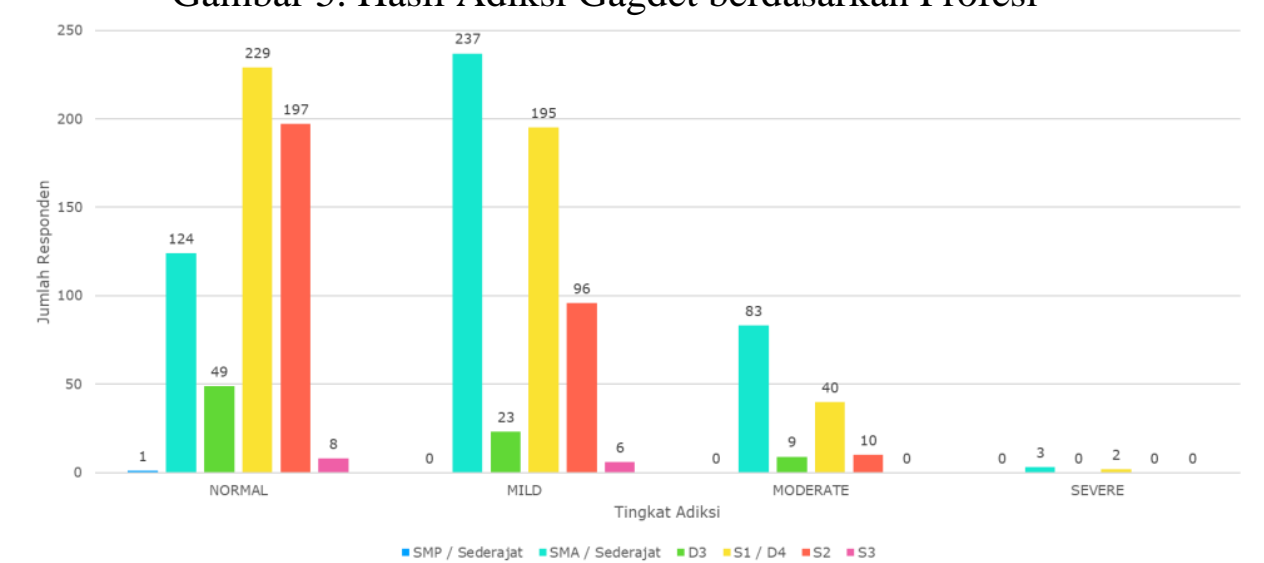

Gambar 6. Hasil Adiksi Gagdet berdasarkan Tingkat Pendidikan

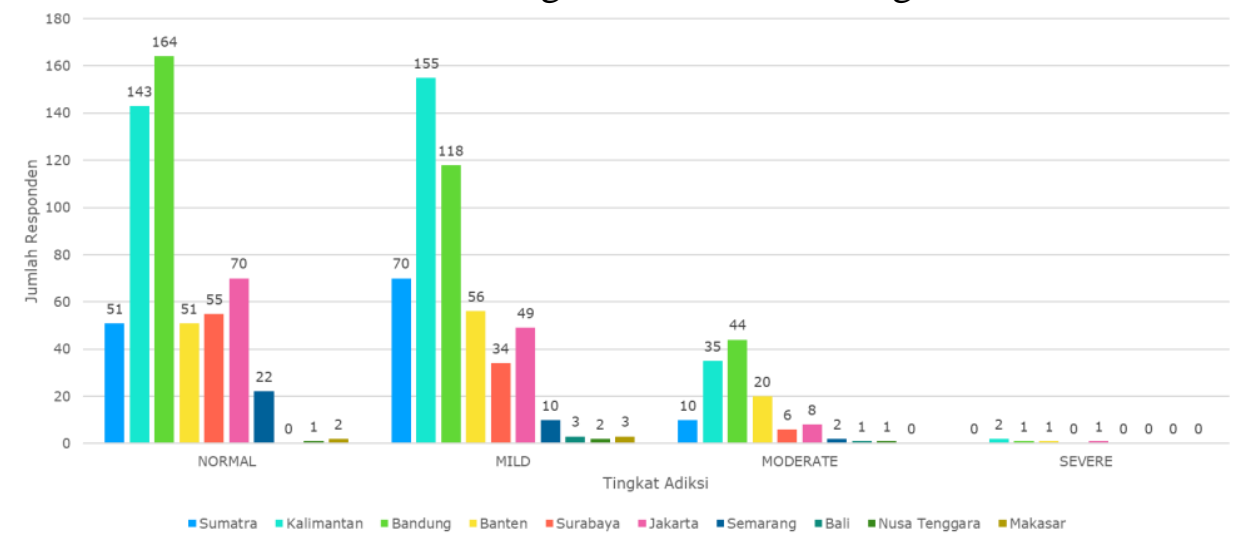

Gambar 7. Hasil Adiksi Gagdet berdasarkan Domisili

Gambar 8-12 menunjukan hasil adiksi media sosial berdasarkan beberapa variable uji jenis kelamin, kelompok umur, profesi, tingkat pendidikan dan domisili: 


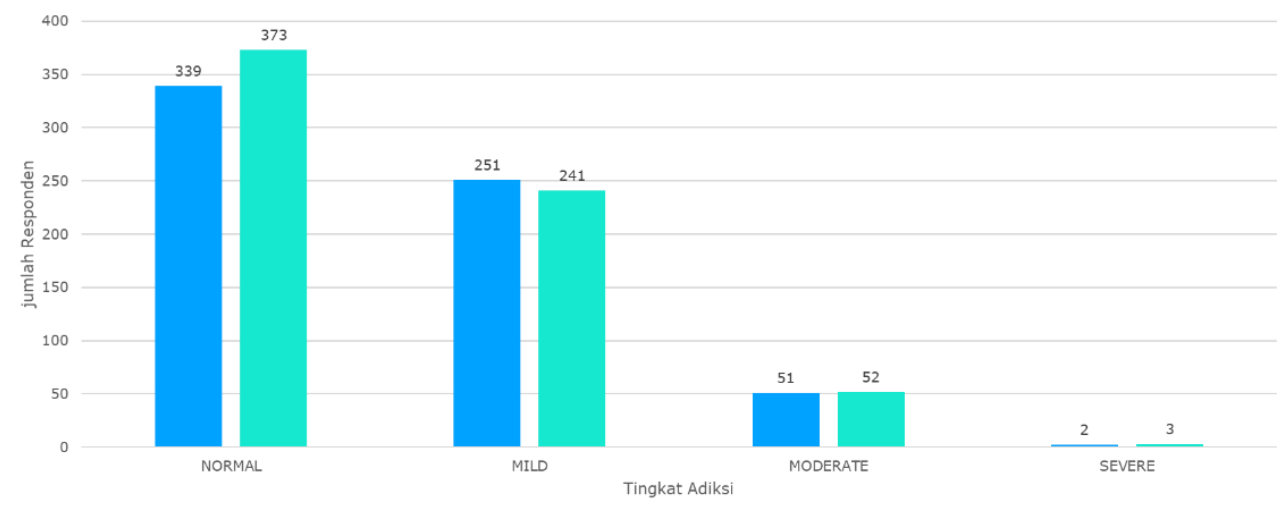

Gambar 8. Hasil Adiksi Media sosial berdasarkan Jenis Kelamin

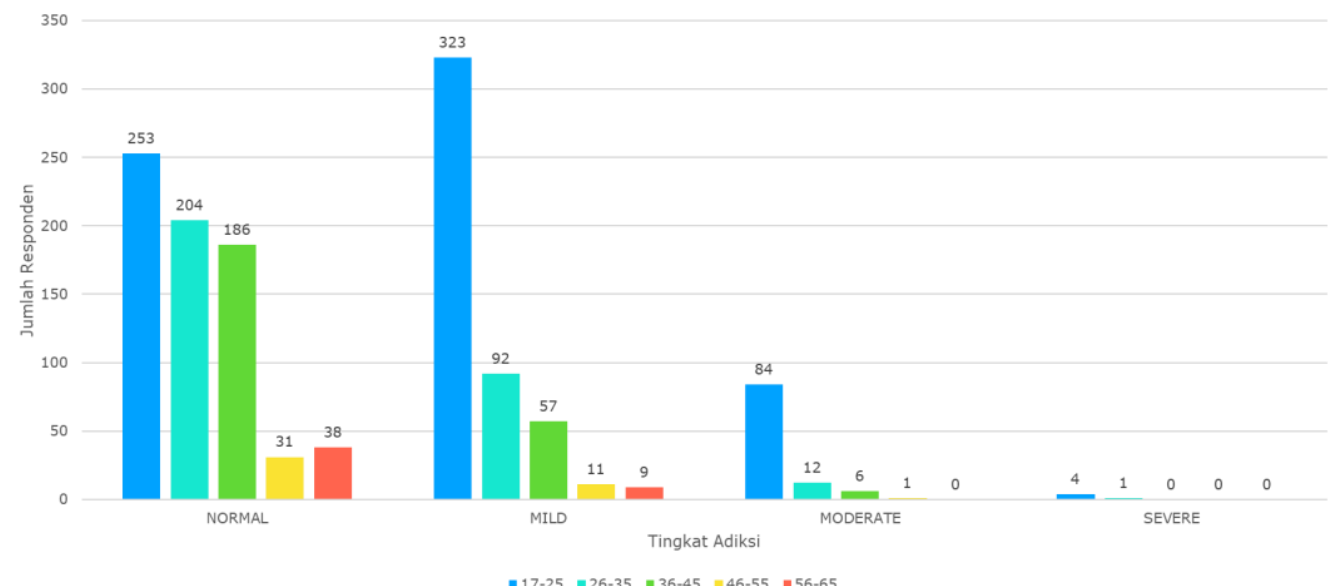

Gambar 9. Hasil Adiksi Media sosial berdasarkan Kelompok Umur

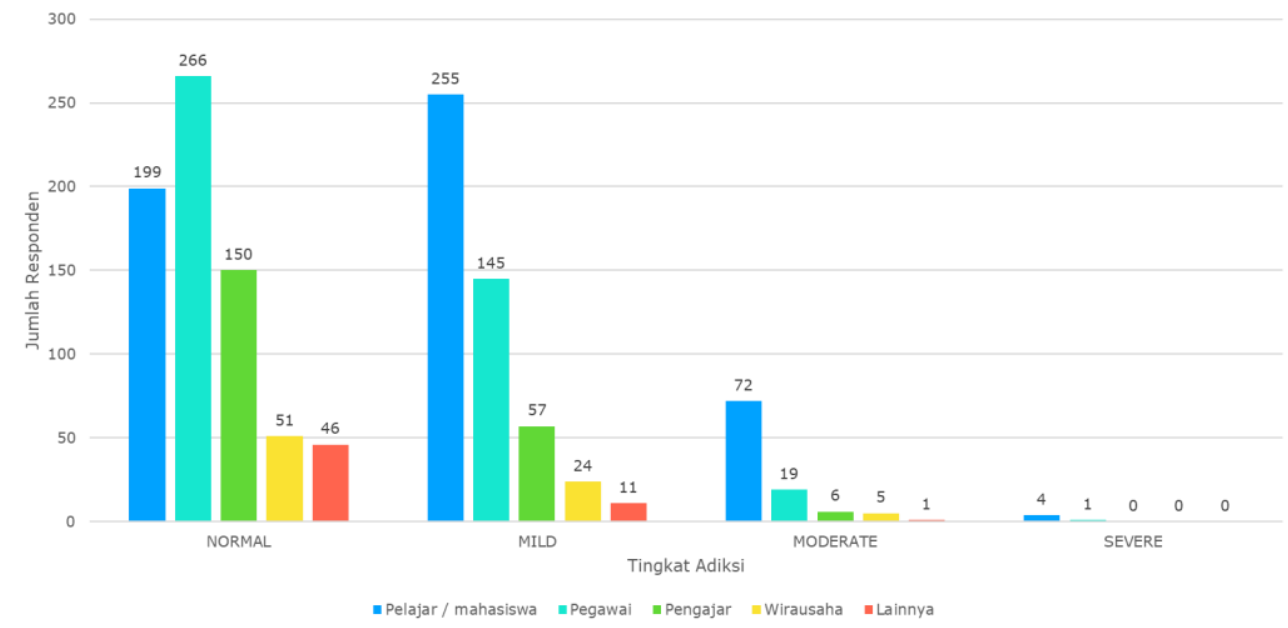

Gambar 10. Hasil Adiksi Media sosial berdasarkan Profesi 


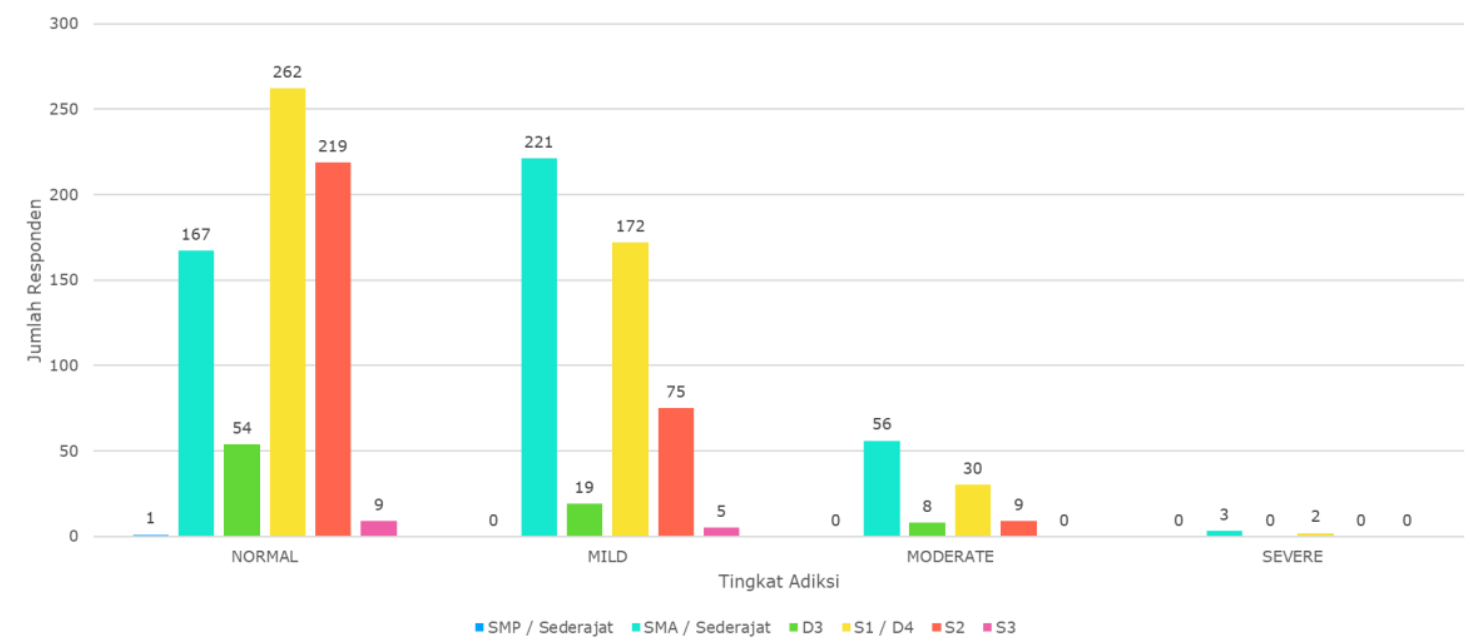

Gambar 11. Hasil Adiksi Media sosial berdasarkan Pendidikan

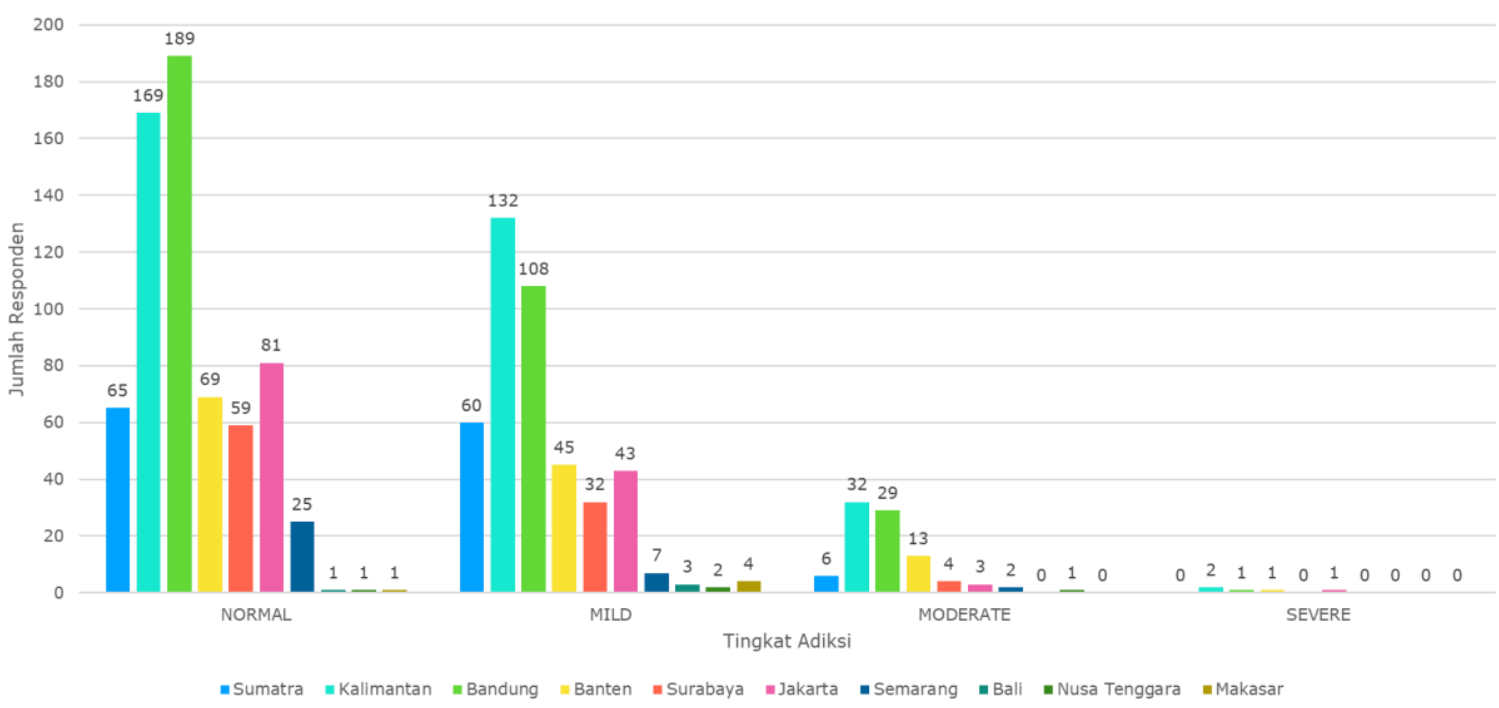

Gambar 12. Hasil Adiksi Media sosial berdasarkan Domisili

\subsection{Pengujian Hipotesis}

Hipotesis utama pada penelitian ini yaitu bahwa fenomena adiksi gadget dan media sosial merupakan kenyataan saintifik di Indonesia jika terdapat penduduk Indonesia yang teradiksi gadget dan media sosial. Untuk mendukung hipotesis tersebut dilakukan uji variable yang berpengaruh terhadap adiksi maka hipotesis terbukti benar.

Uji variable yang dilakukan antara lain hipotesis hubungan antara umur, profesi, Pendidikan, domisili, jenis kelamin, rata-rata jam per hari penggunaan gadget dan atau media social dan lama waktu penggunaan gadget dan atau media sosial (tahun). Alat uji yang digunakan yaitu perhitungan uji chi-square dimana variable yang diuji akan berpengaruh terhadap adiksi jika nilai p-value yang dihasilkan kurang dari 0.05. Tabel 3 menunjukan hasil perhitungan uji chi-square untuk setiap hipotesis.

Tabel 3. Hasil Uji Chi-Square untuk semua variable uji

\begin{tabular}{|l|l|l|l|}
\hline Variable Uji & Jenis Adiksi & $\begin{array}{l}\text { Nilai } \\
\text { P-value }\end{array}$ & Kesimpulan \\
\hline Jenis Kelamin & Gadget & 0.097 & Tidak Berpengaruh \\
\hline Umur & Gadget & 0.000 & Berpengaruh \\
\hline
\end{tabular}




\begin{tabular}{|l|l|l|l|}
\hline Profesi & Gadget & 0.000 & Berpengaruh \\
\hline Pendidikan & Gadget & 0.000 & Berpengaruh \\
\hline Domisili & Gadget & 0.000 & Berpengaruh \\
\hline Rata-rata penggunaan gadget (jam/hari) & Gadget & 0.000 & Berpengaruh \\
\hline Lama Waktu penggunaan gadget & Gadget & 0.605 & Tidak Berpengaruh \\
\hline Jenis Kelamin & Media Sosial & 0.898 & Tidak Berpengaruh \\
\hline Umur & Media Sosial & 0.000 & Berpengaruh \\
\hline Profesi & Media Sosial & 0.000 & Berpengaruh \\
\hline Pendidikan & Media Sosial & 0.000 & Berpengaruh \\
\hline Domisili media sosial & Media Sosial & 0.011 & Berpengaruh \\
\hline $\begin{array}{l}\text { Rata-rata penggunaan Sosial } \\
\text { (jam/hari) }\end{array}$ & 0.000 & Berpengaruh \\
\hline Lama Waktu penggunaan media sosial & Media Sosial & 0.307 & Tidak Berpengaruh \\
\hline Rata-rata penggunaan gadget (jam/hari) & Media Sosial & 0.000 & Berpengaruh \\
\hline Lama Penggunaan gadget (tahun) & Media Sosial & 0.652 & Tidak Berpengaruh \\
\hline
\end{tabular}

Dari hasil perhitungan uji chi-square dapat disimpulkan bahwa umur, profesi, tingkat Pendidikan, domisili, rata-rata penggunaan gadget (jam/hari) dan lama waktu penggunaan gadget(tahun) berpengaruh pada adiksi gadget. Sedangkan jenis kelamin tidak berpengaruh terhadap adiksi gadget. Serta umur, profesi, tingkat Pendidikan, domisili, rata-rata penggunaan media sosial (jam/hari) dan rata-rata penggunaan gadget $(\mathrm{jam} / \mathrm{hari})$ berpengaruh terhadap adiksi media sosial. Sedangkan jenis kelamin dan lama waktu penggunaan media sosial (tahun) tidak berpengaruh terhadap adiksi media sosial. Rata-rata penggunaan gadget (jam/hari) berpengaruh terhadap adiksi media sosial sedangkan lama waktu penggunaan gadget (tahun) tidak berpengaruh terhadap adiksi media sosial.

\subsection{Estimasi Jumlah Penduduk Indonesia yang Teradiksi Gadget dan Media Sosial}

Berdasarkan hasil survey dapat diperkirakan jumlah penduduk Indonesia yang teradiksi gadget dan media sosial menggunakan metode confidence interval, dengan jumlah penduduk Indonesia yang menggunakan gadget sejumlah 178.89 juta jiwa [18] dan pengguna media sosial aktif sejumlah 150 juta jiwa [19]. Sehingga estimasi penduduk Indonesia yang teradiksi gadget yaitu:

a. 71.16 juta -80.73 juta jiwa teradiksi gadget tingkat rendah

b. 16.35 juta -22.36 juta jiwa teradiksi gadget tingkat sedang

c. 85.30 ribu -1.27 juta jiwa teradiksi gadget tingkat tinggi

Sedangkan untuk estimasi penduduk Indonesia yang teradiksi media sosial yaitu:

a. 52.32 juta -60.17 juta jiwa teradiksi media sosial tingkat rendah

b. 9.59 juta -13.95 juta jiwa teradiksi media sosial tingkat sedang

c. 71.53 ribu -1.07 juta jiwa teradiksi media sosial tingkat tinggi

\subsection{Kajian Adiksi gadget dan Media Social dari sisi Filsafat Ilmu}

Realitas Adiksi Gadget dan Media Sosial ini perlu difalsifikasi agar tidak menjadi pseudoscience. Dari hasil penelitian yang telah dilakukan, Adiksi Gadget dan Media Sosial dikatakan sains karena beberapa aspek antara lain telah dilakukan pengujian terhadap kuesioner yang diujikan, kriteria dan instrumen pengukuran sangat terbuka untuk diuji dan dikembangkan lebih lanjut. Hal tersebut sesuai dengan prinsip Karl Popper yang memberikan gagasan penelitian berbasis falsifikasi [20], [21]. 
Adiksi Gadget dan Media Sosial jika dikaitkan dengan teori scientific revolution Thomas Kuhn masih berada pada fase krisis. Sains normal pada kasus ini yaitu teori adiksi pada kasus lain seperti adiksi rokok, minuman keras dan obat-obatan terlarang. Selanjutnya mulai muncul anomali-anomali yang terjadi pada kasus adiksi dan tidak dapat diselesaikan dengan teknik adiksi biasanya. Hal ini ditandai dengan banyaknya kasus-kasus yang terjadi dikarenakan oleh gadget dan media sosial. Maka saat ini adiksi dikatakan mengalami krisis pada bidang adiksi gadget dan media sosial. Masalah utama yang harus diselesaikan adalah bagaimana menemukan teori-teori baru, metode-metode untuk mengukur dan mengatasi adiksi gadget dan media sosial. Diharapkan dengan terkumpulnya semua teori dan metode tentang adiksi gadget dan media sosial dapat menjawab krisis yang terjadi sehingga menghasilkan sains revolusioner [22].

\section{Kesimpulan}

Dari 1601 responden terbukti bahwa $46.16 \%$ responden mengalami kecanduan ringan, $10.56 \%$ responden mengalami kecanduan level sedang, dan $0.31 \%$ responden mengalami kecanduan yang sangat kuat terhadap gadget. Sedangkan hasil untuk adiksi media sosial, $38.37 \%$ responden mengalami kecanduan ringan, $7.87 \%$ responden mengalami kecanduan level sedang, dan $0.31 \%$ responden mengalami kecanduan yang sangat kuat terhadap media sosial.

Dalam penelitian ini dilakukan uji variable yang meliputi umur, jenis kelamin, profesi, tingkat Pendidikan, domisili, rata-penggunaan gadget dan atau media sosial (jam/hari), lama waktu penggunaan gadget dan atau media sosial (tahun) untuk melihat pengaruh setiap variable uji terhadap adiksi gadget dan media sosial. Dari hasil perhitungan uji chi-square dapat disimpulkan bahwa umur, profesi, tingkat Pendidikan, domisili, rata-rata penggunaan gadget (jam/hari) dan lama waktu penggunaan gadget(tahun) berpengaruh pada adiksi gadget. Serta umur, profesi, tingkat Pendidikan, domisili, rata-rata penggunaan media sosial (jam/hari) dan rata-rata penggunaan gadget (jam/hari) berpengaruh terhadap adiksi media sosial.

Berdasarkan hal-hal yang telah disebutkan diatas maka Adiksi Gadget dan Media Sosial dikatakan sains dan bukan pseudo sains karena telah memenuhi ciri sains yaitu logis, empiris, dan dapat difalsifikasi. Sehingga perlu perhatian khusus dari masyarakat akan adanya adiksi gadget dan media social ini, agar adiksi ini dapat diantisipasi dan gejala-gejala yang ditimbulkan dapat diminimalisir.

\section{Daftar Pustaka}

[1] F. Rahmandani, A. Tinus, And M. M. Ibrahim, "Analisis Dampak Penggunaan Gadget (Smartphone) Terhadap Kepribadian Dan Karakter (Kekar) Peserta Didik Di Sma Negeri 9 Malang," Jch, Vol. 3, No. 1, P. 18, May 2018.

[2] D. R. Desiningrum And Y. Indriana, "Intensi Penggunaan Gadget Dan Kecerdasan Emosional Pada Remaja Awal,” P. 7, 2017.

[3] "Statista.Com." [Online]. Available: Https://Www.Statista.Com/Statistics/498366/Number-Of-Mobile-CellularSubscriptions-In-Indonesia/

[4] E. P. Juwita, D. Budimansyah, And S. Nurbayani, "Peran Media Sosial Terhadap Gaya Hidup Siswa," Sosietas, Vol. 5, No. 1, Mar. 2015 [Online]. Available: Http://Ejournal.Upi.Edu/Index.Php/Sosietas/Article/View/1513. [Accessed: 06-Dec2019] 
[5] S. F. Soliha, "Tingkat Ketergantungan Pengguna Media Sosial Dan Kecemasan Sosial," Vol. 4, No. 1, P. 10, 2015.

[6] R. A. Prasojo, D. A. Maharani, And M. O. Hasanuddin, "Mengujikan Internet Addiction Test (Iat) Ke Responden Indonesia,” Ina-Rxiv, Preprint, Dec. 2018 [Online]. Available: Https://Osf.Io/7ag4w. [Accessed: 06-Dec-2019]

[7] L. A. Arifin And F. A. Rahmadi, "Hubungan Tingkat Kecanduan Gadget Dengan Prestasi Belajar Siswa Usia 10 - 11 Tahun,” Vol. 6, No. 2, P. 9, 2017.

[8] M. Aziz, "Pengaruh Penggunaan Handphone Terhadap Interaksi Sosial Remaja Di Desa Dayah Meunara Kecamatan Kutamakmur Kabupaten Aceh Utara,” Vol. 4, No. 1, P. 21, 2018.

[9] A. R. Asif And F. A. Rahmadi, "Hubungan Tingkat Kecanduan Gadget Dengan Gangguan Emosi Dan Perilaku Remaja Usia 11-12 Tahun," Vol. 6, No. 2, P. 10, 2017.

[10] "Social Media Addiction." [Online]. Available: Https://Www.Addictioncenter.Com/Drugs/Social-Media-Addiction

[11] J. Rakhmat, Psikologi Komunikasi. Bandung: Remaja Rosdakarya, 2011.

[12] J. Lanier, Ten Arguments for Deleting Your Social Media Accounts Right Now. New York: Henry Holt and Company, 2018.

[13] M. D. Griffiths Et Al., "Working Towards an International Consensus on Criteria for Assessing Internet Gaming Disorder: A Critical Commentary On Petry Et Al. (2014): Assessment Of Internet Gaming Disorder," Addiction, Vol. 111, No. 1, Pp. 167-175, Jan. 2016.

[14] D. J. Kuss And M. D. Griffiths, Internet Addiction in Psychoterapy. Palgrave Pivot, 2015.

[15] K. S. Young, "Internet Addiction: A Handbook and Guide To Evaluation And Treatment," New York, P. 314, 2011.

[16] Badan Pusat Statistik, Perempuan Dan Laki-Laki Di Indonesia 2018.

[17] "Depkes Ri Tahun 2009.” [Online]. Available: Depkes.Go.Id

[18] "Kominfo.Go.Id." [Online]. Available: Kominfo.Go.Id

[19] "Websindo.Com." [Online]. Available: Websindo,Com

[20] K. Popper, The Logic of Scientific Discovery. 2005 [Online]. Available: Http://Public.Ebookcentral.Proquest.Com/Choice/Publicfullrecord.Aspx?P=254228. [Accessed: 29-Oct-2019]

[21] D. Mahayana, Filsafat Ilmu Pengetahuan. Bandung: Penerbit Itb, 2018.

[22] T. S. Kuhn And I. Hacking, The Structure of Scientific Revolutions, Fourth Edition. Chicago; London: The University of Chicago Press, 2012. 